\title{
Reliable Earlier and Causative Biomarker in newly Diagnosed Hypothyroid Cases-Vitamin D: A Case-control Study
}

\author{
AG Thivyah Prabha
}

\begin{abstract}
Background: In Indian population there are 42 million people suffering from hypothyroidism. Hence, even though thyroidstimulating hormone (TSH) has been used as the diagnostic marker of hypothyroidism, there arises a need to evaluate an earlier and a causative marker for hypothyroidism and thus it could be a better predictor of the disease in the earlier stages only.
\end{abstract}

Aims and objectives: The aim of the study is to identify a reliable earlier and one of the causative biomarkers of hypothyroidism.

Materials and methods: This study was conducted in 200 cases of newly diagnosed hypothyroidism and 200 controls of healthy individuals. Vitamin D, intact parathyroid hormone, TSH, triiodothyronine, thyroxine, and calcium were measured.

Results: It was observed that vitamin D was significantly decreased in hypothyroid cases. There was a negative correlation between vitamin $\mathrm{D}$ and TSH.

Conclusion: Vitamin $\mathrm{D}$ being one of the causative factors in thyroid disorders should be included as a routine parameter of analysis in hypothyroid cases and supplementation of vitamin $\mathrm{D}$ also to be initiated by the clinicians to avoid the progression to overt hypothyroidism in the newly diagnosed cases.

Keywords: Calcium, Hypothyroidism, Intact parathyroid hormone, Thyroid-stimulating hormone, Vitamin D.

How to cite this article: Prabha AGT. Reliable Earlier and Causative Biomarker in newly Diagnosed Hypothyroid CasesVitamin D: A Case-control Study. Indian J Med Biochem 2017;21(1):54-57.

Source of support: Nil

Conflict of interest: None

\section{INTRODUCTION}

In Indian population, there are 42 million hypothyroid cases. ${ }^{1}$ Thus, there arises a need to identify an earlier causative and reliable biomarker to help in the early

Assistant Professor

Department of Biochemistry, East Point College of Medical Sciences and Research Centre, Bengaluru, Karnataka, India

Corresponding Author: AG Thivyah Prabha, Assistant Professor, Department of Biochemistry, East Point College of Medical Sciences and Research Centre, Bengaluru, Karnataka India, Phone: +919686653148, e-mail: drthivyahprabha@ gmail.com diagnosis of hypothyroidism and in the therapeutic aspect also. Vitamin D, being a hormone, acts on various types of cells and plays multiple roles. Other than bone metabolism, it has a causative role in various diseases ${ }^{2,3}$ like diabetes mellitus, ${ }^{4}$ cancer, ${ }^{5}$ multiple sclerosis, ${ }^{6}$ autoimmune diseases, ${ }^{7}$ and atherosclerosis. ${ }^{8}$ Vitamin D not only acts through the immune-mediated process but also acts on the thyroid follicular cells by inhibiting directly the thyrotropin-mediated stimulation of iodine uptake in dose-dependent manner. ${ }^{9}$ A population-based study has observed low thyroid-stimulating hormone (TSH) among younger individuals. ${ }^{10}$ Hence, the reliability of TSH in the diagnosis of hypothyroidism in younger individuals is affected. Thus, in the present study, the relation between TSH and vitamin D with triiodothyronine (T3) and thyroxine (T4) at the time of diagnosis of hypothyroid cases has been evaluated.

\section{MATERIALS AND METHODS}

Two hundred cases of newly diagnosed hypothyroidism and 200 healthy individuals as controls were included in this case-control study. Written consent was taken from all the participants in the study. Complete history was taken. They belonged to the age group of 15 to 30 years. None of the participants were started on treatment for hypothyroidism. Patients with renal diseases, hepatic disease, rheumatologic disease, diabetes mellitus, alcoholics, dermatologic diseases, and child birth in last 1 year were excluded from the study. Control groups of people were those who visited the hospital for health checkup and the volunteers of blood donations. Venous samples were collected after 12 hours of fasting in plain tubes. For all the participants of the study, plasma glucose (glucose oxidase and peroxidase method), serum creatinine (modified Jaffe's kinetic method), and blood urea (urease method) were evaluated to rule out the basic pathology and it was done in Beckman Coulter AU 480. Calcium was done by o-cresolphthalein method. The TSH and intact parathyroid hormone (iPTH) were done by chemiluminescence in Beckman access 2. Vitamin $\mathrm{D}[25(\mathrm{OH}) \mathrm{D}]$ was done by high performance liquid chromatography method. Vitamin D of $<30 \mathrm{ng} / \mathrm{mL}$ was considered as insufficiency and vitamin D of $<20 \mathrm{ng} / \mathrm{mL}$ 
Reliable Earlier and Causative Biomarker in Newly Diagnosed Hypothyroid Cases

Table 1: Characteristics of the physical parameters in the study group

\begin{tabular}{llll}
\hline Parameters & Controls $n=200$ & Cases $n=200$ & $p$-value \\
\hline Sex & $\mathrm{M}-43 \%(86)$ & $\mathrm{M}-40 \%(80)$ & $>0.05$ \\
& $\mathrm{~F}-57 \%(114)$ & $\mathrm{F}-60 \%(120)$ & \\
Age (years) & $20 \pm 8.1$ & $21 \pm 7.3$ & $>0.05$ \\
\hline
\end{tabular}

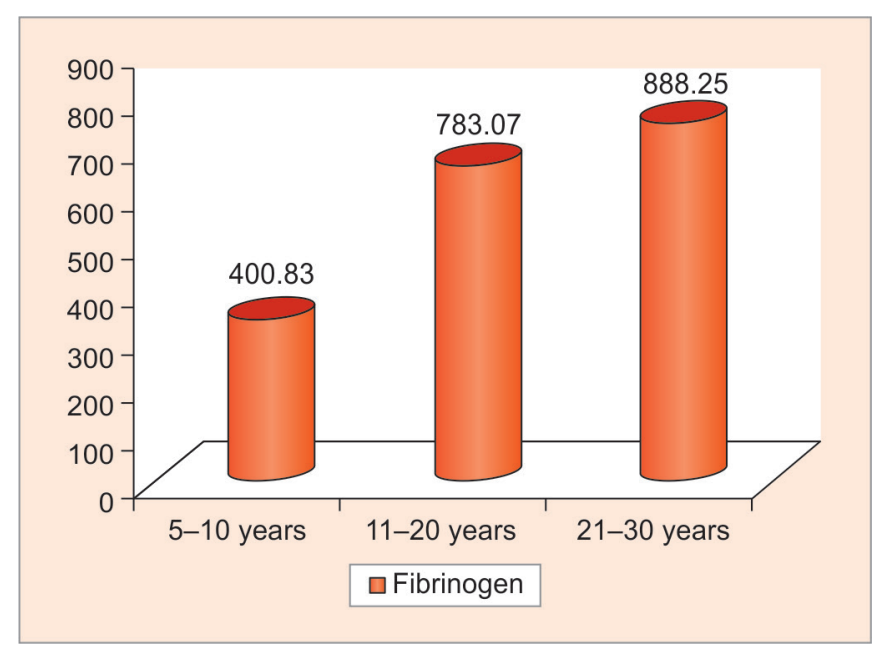

Graph 1: Characteristics of calcium, vitamin D, and iPTH in the study group

was considered as deficiency. ${ }^{11}$ The reference range were $1.2-4.4 \mathrm{pg} / \mathrm{mL}$ for T3, 0.8-2.0 ng/dL for T4, and 0.5-5.0 $\mathrm{mU} / \mathrm{L}$ for TSH. ${ }^{12}$ The statistical analysis was done using the Statistical Package for the Social Sciences, version 20. Mean, standard deviation (SD), p-value, and Pearson's correlation were calculated; $\mathrm{p}$-value $<0.05$ was considered as significant and indicated by * mark.

\section{RESULTS}

The mean, SD, p-value, and Pearson's correlation (r) were calculated for the age, sex, serum calcium, serum vitamin $\mathrm{D}$, serum $\mathrm{iPTH}$, and thyroid profile. Age group of the cases and controls were matching. In age and sex categories, there were no statistical significance and $p$-value was $>0.05$. For serum calcium, serum vitamin $D$, serum iPTH, and thyroid profile, $\mathrm{p}$-values were $<0.000$ and hence statistical significance was seen. The characteristics of the physical parameters and the $p$ values are shown in Table 1.

The characteristics of the biochemical parameters and the $\mathrm{p}$ values are shown in Table 2 and Graphs 1 and 2. The TSH and iPTH values were higher in the hypothyroid cases (6.92 \pm 0.97 and $57.6 \pm 3.30$ respectively). The mean values of serum calcium and vitamin $\mathrm{D}$ were lower in hypothyroid cases: $7.92 \pm 1.77$ and $14.79 \pm 2.11$ respectively.

The comparison of TSH, serum calcium, and vitamin D values according to the sex distribution was statistically insignificant and it is shown in Table 3 and Graph 3. In
Table 2: Characteristics of the biochemical parameters in the study group

\begin{tabular}{|c|c|c|c|}
\hline Parameters & $\begin{array}{l}\text { Controls } \\
n=200\end{array}$ & $\begin{array}{l}\text { Cases } \\
n=200\end{array}$ & $p$-value \\
\hline Serum calcium (mg/dL) & $10.37 \pm 1.55$ & $7.92 \pm 1.77$ & 0 \\
\hline Serum vitamin $D(\mathrm{ng} / \mathrm{mL})$ & $44.53 \pm 14.91$ & $14.79 \pm 2.11$ & 0 \\
\hline Serum iPTH $(\mathrm{pg} / \mathrm{mL})$ & $36.8 \pm 1.91$ & $57.6 \pm 3.30$ & 0 \\
\hline Serum TSH (mU/L) & $3.66 \pm 0.91$ & $6.92 \pm 0.97$ & 0 \\
\hline Serum T3 (pg/mL) & $2.94 \pm 1.01$ & $1.08 \pm 1.02$ & 0 \\
\hline Serum T4 (ng/dL) & $1.59 \pm 0.30$ & $0.64 \pm 0.46$ & 0 \\
\hline
\end{tabular}

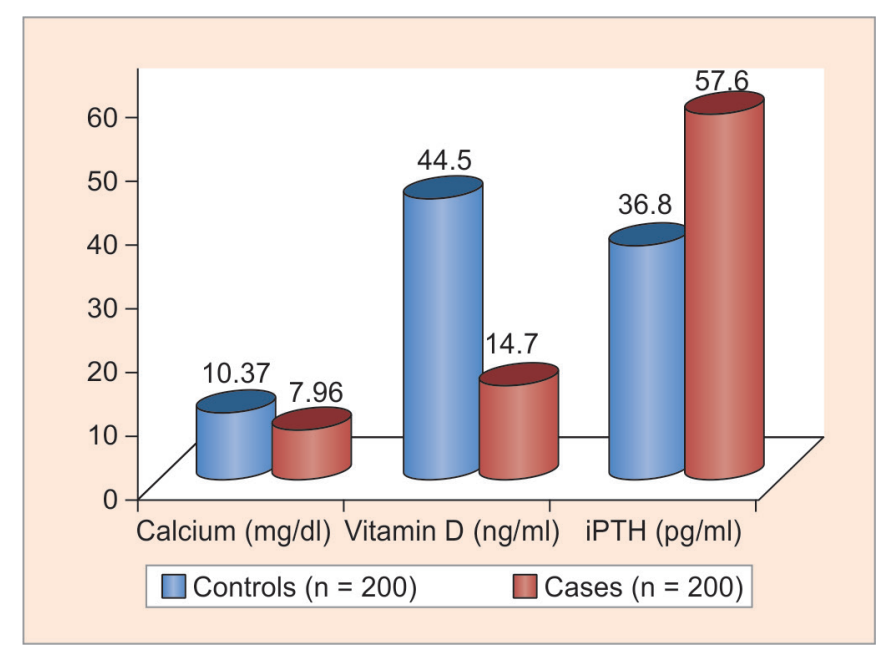

Graph 2: Characteristics of thyroid profile in the study group

Table 3: Levels of parameters according to sex in the hypothyroid patients

\begin{tabular}{llll}
\hline & \multicolumn{2}{c}{ Cases } & \\
\cline { 2 - 3 } & $\begin{array}{l}\text { Male } \\
(n=80)\end{array}$ & $\begin{array}{l}\text { Female } \\
(n=120)\end{array}$ & p-value \\
\hline Parameters & $7.92 \pm 2.13$ & $7.89 \pm 1.55$ & 0.988 \\
Serum calcium $(\mathrm{mg} / \mathrm{dL})$ & $58.4 \pm 3.12$ & $56.3 \pm 3.01$ & 0.498 \\
Serum iPTH $(\mathrm{pg} / \mathrm{mL})$ & $15.58 \pm 2.27$ & $14.27 \pm 1.89$ & 0.213 \\
Serum vitamin D $(\mathrm{ng} / \mathrm{mL})$ & 150.90 & 0.597 \\
Serum TSH $(\mathrm{mU} / \mathrm{L})$ & $6.80 \pm 1.02$ & $7.05 \pm 0.96$ & 0 \\
\hline
\end{tabular}

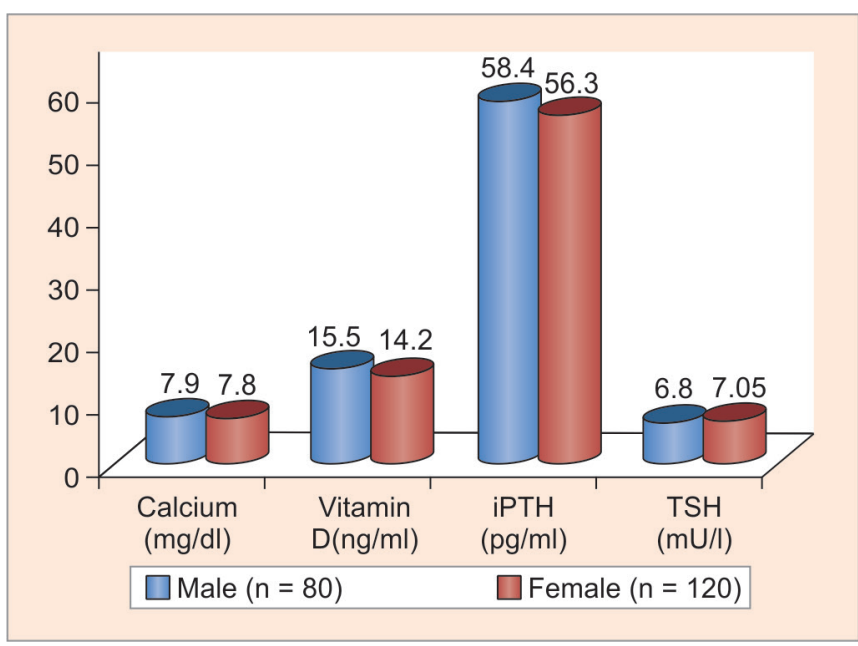

Graph 3: Levels of parameters according to sex in the hypothyroid patients 
Table 4: Correlation between parameters in cases

\begin{tabular}{ll}
\hline Parameters & Vitamin $D$ \\
\hline Calcium & $r=(0.82)$ \\
Intact PTH & $r=(0.76)$ \\
TSH & $r=(-0.52)$ \\
T3 & $r=(0.63)$ \\
T4 & $r=(0.04)$ \\
\hline
\end{tabular}

hypothyroid cases, TSH was higher and serum calcium and vitamin $\mathrm{D}$ were on lower side and were statistically significant with $\mathrm{p}$-value $<0.000$.

In control group, there is a positive correlation between the vitamin $\mathrm{D}$ and each of calcium $(\mathrm{r}=0.76)$ and $\mathrm{T} 3(\mathrm{r}=0.59)$. In these cases, there was a significant negative correlation between vitamin D and TSH $(r=-0.52)$. There was also a significant negative correlation between calcium and TSH $(\mathrm{r}=-0.40)$. The correlations among the parameters are shown in Table 4.

\section{DISCUSSION}

Vitamin D, being a steroid hormone, not only plays a role in bone metabolism but also has a role in the pathogenesis of diabetes mellitus, hypertension, cancer, and autoimmune diseases. Vitamin D acts on 36 cell types that have vitamin D receptors (VDRs) including the thyroid gland. The vitamin $\mathrm{D}$ deficiency causes the abnormal functioning of the thyroid gland and presents with the symptoms of the hypothyroidism. ${ }^{8,13}$ Moreover, in the hypothyroid patients, the intestinal motilities were sluggish and it causes the malabsorption of vitamin $\mathrm{D}$ and it goes as a vicious cycle. ${ }^{14} \mathrm{~A}$ recent study has shown that the vitamin D deficiency leads to Graves' disease and the other autoimmune diseases of the thyroid gland. ${ }^{15,16} \mathrm{In}$ India, it was thought that vitamin D deficiency was very uncommon as it is located between $8.4^{\circ} \mathrm{N}$ and $37.6^{\circ} \mathrm{N}$ latitude receiving a lot of sunshine. ${ }^{17}$ But many epidemiological studies have shown that in Indian population, 50 to $90 \%$ people have vitamin D deficiency due to the poor oral intake of calcium. ${ }^{3}$ Vitamin D gene polymorphism plays a main role in the altered action of the VDRs in the thyroid gland cells. Hence, the presentation of either hypothyroidism or even Graves' disease may be seen in patients depending on the basic gene polymorphism. ${ }^{18}$ Thus vitamin D gene polymorphism causes thyroid diseases and it has been revealed that vitamin D plays one of the causative roles in thyroid disorders. Vitamin $\mathrm{D}$ $\left[1,25-(\mathrm{OH})_{2} \mathrm{D}\right]$ is not used as the indicator of the vitamin $\mathrm{D}$ status in the serum as it has the short half-life of 15 hours only. ${ }^{19}$ Moreover, vitamin $\mathrm{D}\left[1,25-(\mathrm{OH})_{2} \mathrm{D}\right]$ values will decrease in the serum of cases with severe vitamin $D$ deficiencies. ${ }^{20,21}$ Hence, usually serum concentration of $25(\mathrm{OH}) \mathrm{D}$ is measured as it has longer half-life of 15 days, which was followed in the present study also. Even though increased TSH is used as the marker of hypothyroidism for long time, it is only a feedback mechanism to reduce $\mathrm{T} 3$ and $\mathrm{T} 4$ and it will elevate during the time the disease has already progressed. But vitamin D playing the role in the pathogenesis of the disease will get altered at the early stages of the hypothyroidism.

In the present study, serum calcium and vitamin D levels were on lower side in cases when compared with the controls. Intact PTH was increased as a compensatory mechanism to reduce calcium and vitamin $\mathrm{D}$. There was also a significant negative correlation between TSH and vitamin D levels in the cases at the time of diagnosis of hypothyroidism. In vitamin D deficiency individuals, iPTH increases as they are not able to maintain the serum calcium levels. In this study also, iPTH levels were elevated in accordance with the vitamin D levels and calcium levels. The target cells of iPTH are less responsive to the $\mathrm{iPTH}$ in hypothyroid cases, which also aggravates the vitamin D deficiency in the hypothyroid cases. ${ }^{22}$ This study shows the decreased levels of vitamin D in females than males, but it was not significant. The other studies have also mentioned the nonsignificant decrease in vitamin D levels among males and females. ${ }^{23,24} \mathrm{~A}$ study conducted in Japan has shown vitamin D deficiency in $40 \%$ females and $20 \%$ males with thyroid disorders, which was statistically significant $(\mathrm{p}<0.005) .{ }^{14}$

Thus, in cases of hypothyroidism, the vitamin D levels should be analyzed as a routine to treat one of the causative factors of the disease pathology. Moreover, vitamin D is one of the modifiable risk factors for hypothyroidism and hence it is necessary to include vitamin D analysis as a routine in hypothyroid cases and to initiate the treatment of vitamin D. On following the analysis of vitamin D as a routine in practice, it becomes possible to diagnose hypothyroid cases in the early stages and to prevent the progression of the disease.

\section{CONCLUSION}

Hypothyroid cases have vitamin D deficiency at the time of diagnosis and there is an important role of vitamin $\mathrm{D}$ in the pathogenesis of thyroid disorders. There is a significant negative correlation between vitamin $\mathrm{D}$ and TSH in newly diagnosed hypothyroid cases, indicating the causative role of vitamin D in hypothyroidism. Hence, there arises a need to analyze vitamin D in all cases of hypothyroidism and to supplement vitamin $\mathrm{D}$ as a routine treatment to protect the cases from developing overt hypothyroidism in the future. 


\section{LIMITATIONS AND RECOMMENDATIONS}

The present study has not attempted to exclude the effect of smoking, body mass index, and other factors which could alter the TSH levels. Moreover, only the newly diagnosed cases have been included in the study and attempts should be taken to follow the therapeutic effect of vitamin D on hypothyroid cases.

\section{REFERENCES}

1. Unnikrishnan AG, Menon UV. Thyroid disorders in India: An epidemiological perspective. Indian J Endocrin Metab 2011;15(2):S78-S81.

2. Holick MF. Medical progress: vitamin D deficiency. N Engl J Med 2007 Jul;357(3):266-281.

3. Harynarayan CV, Joshi SR. Vitamin D status in India - its implications and remedial measures. J Assoc Physicians India 2009 Jan;57:40-48.

4. Pittas AG, Lau J, Hu FB, Dawson-Hughes B. Review of the role of vitamin D and calcium in type 2 diabetes. A systematic review and meta-analysis. J Clin Endocrinol Metab 2007 Jun;92(6):2017-2029.

5. Garland CF, Gorham ED, Mohar SB, Garland C. Vitamin D for cancer prevention: global preservative. Ann Epidemiol 2009 Jul;19(7):468-483.

6. Cranney A, Horsley T, O’Donnell S, Weiler H, Puil L, Ooi D, Atkinson S, Ward L, Moher D, Hanley D, et al. Effectiveness and safety of vitamin D in relation to bone health. Evid Rep Technol Assess (Full Rep) 2007 Aug;158:1-235.

7. Cutolo M, Otsa K. Vitamin D, immunity and lupus. Lupus 2008 Jan;17(1):6-10.

8. Wang TJ, Pencina MJ, Booth SL, Jacques PF, Ingelsson E, Lanier K, Benjamin EJ, D'Agostino RB, Wolf M, Vasan RS. Vitamin D deficiency and risk of cardiovascular disease. Circulation 2008 Jan;117(4):503-511.

9. Berg JP, Liane KM, Bjorhovde SB, Bjøro T, Torjesen PA, Haug E. Vitamin D receptor binding and biological effects of cholecalciferol analogues in rat thyroid cells. J Steroid Biochem Mol Biol 1994 Aug;50(3-4):145-150.

10. Chailurkit LO, Aekplakom W, Ongphinphadhankul B. High vitamin D status in younger individuals in associated with low circulating thyrotropin. Thyroid 2013 Jan;23(1):25-30.

11. Chapuy MC, Preziosi P, Maamer M, Arnaud S, Galan P, Hercberg S, Meunier PJ. Prevalence of vitamin D insufficiency in an adult normal population. Osteoporos Int 1997 Sep;7(5): 439-443.

12. Kaplam MM. Clinical perspectives in the diagnosis of thyroid disease. Clin Chem 1999 Aug;45(8 Pt 2):1377-1383.

13. Chopra S, Cherian D, Jacob JJ. The thyroid hormone, parathyroid hormone and vitamin D associated hypertension. Indian J Endocrinol Metab 2001 Oct;15(Suppl 4):S354-S360.

14. Yamashitha H, Noguchi S, Takastu K, Koike E, Murakami T, Watanabe S, Uchino S, Yamashita H, Kawamoto H. High prevalence of vitamin $\mathrm{D}$ deficiency in Japanese female patients with graves. Endocr J 2001 Feb;48(1):63-69.

15. Rotondi M, Chiovato L. Vitamin D deficiency in patients with Graves' disease: probably something more than a causal association. Endocrine 2013 Feb;43(1):3-5.

16. Goswami R, Marwaha RK, Gupta N, Tandon N, Sreenivas V, Tomar N, Ray D, Kanwar R, Agarwal R. Prevalence of vitamin D deficiency and its relationship with thyroid autoimmunity in Asian Indians: a community-based survey. Br J Nutr 2009 Aug;102(3):382-386.

17. Hodgkin P, Hine PM, Kay GH, Lumba GA, Stanbury SW. Vitamin D deficiency in Asians at home and in Britain. Lancet 1973 Jul;2(7822):167-171.

18. Nanderi N, Famood A, Habibi M, Derakhshan F, Balaii H, Motahari Z, Agah MR, Firouzi F, Rad MG, Aghazadeh R, et al. Association of vitamin $D$ receptor gene polymorphisms in Iranian patients with inflammatory bowel disease. J Gasteroenterol Hepatol 2008 Dec;23(12):1816-1822.

19. Jones G. Pharmacokinetics of vitamin D toxicity. Am J Clin Nutr 2008 Aug;88(2):582S-586S.

20. Yetley EA, Brulé D, Cheney MC, Davis CD, Esslinger KA, Fischer PW, Friedl KE, Greene-Finestone LS, Guenther PM, Klurfeld DM, et al. Dietary reference intakes for vitamin D: justification for a review of the 1997 values. Am J Clin Nutr 2009 Mar;89(3):719-727.

21. Wolpowitz D, Gilchrest BA. The vitamin D questions: how much do you need and how should u get it? J Am Acad Dermatol 2006 Feb;54(2):301-317.

22. Adams P, Chalmers TM, Riggs BL Jr, Jones JD. Parathyroid function in spontaneous primary hypothyroidism. J Endocrinol 1968 Apr;40(4):467-475.

23. Elsammak MY, Al-Wossaibi AA, Al-Howeish A, Alsaeed J. High prevalence of vitamin D deficiency in the sunny eastern region of Saudi Arabia: a hospital-based study. East Mediterr Health J 2011 Apr;17(4):317-322.

24. Lippi G, Montagnana M, Meschi T, Borghi L. Vitamin D concentration and deficiency across different ages and genders. Aging Clin Exp Res 2012 Oct;24(5):548-551. 